\title{
Protective Effect of Lactoferrin on Cisplatin-Induced Nephrotoxicity in Rats
}

\author{
Yumi KIMOTO ${ }^{1,2,3)}$, Masaaki NISHINOHARA ${ }^{2)}$, Akihiko SUGIYAMA ${ }^{2)}$, Akihiro HARUNA ${ }^{3)}$ and \\ Takashi TAKEUCHI ${ }^{2} *$ \\ 1) United Graduate School of Veterinary Science, Yamaguchi University, Yamaguchi 753-8515, Japan \\ ${ }^{2)}$ Course of Veterinary Laboratory Medicine, School of Veterinary Medicine, Faculty of Agriculture, Tottori University, Tottori \\ 680-8553, Japan \\ ${ }^{3)}$ Tsuyama Animal Medical Center, Okayama 708-0806, Japan
}

(Received 6 April 2012/Accepted 26 September 2012/Published online in J-STAGE 10 October 2012)

ABSTRACT. Although cisplatin (cis-diamminedichloroplatinum II) is one of the most effective chemotherapeutic agents, its clinical use is limited because of its strong side effects on the kidneys. The aim of this study was to investigate the renoprotective effect of bovine lactoferrin (bLf) in cisplatin-induced renal failure in rats. To assess the renoprotective effect of bLf, oral bLf (300 $\mathrm{mg} / \mathrm{kg}) \mathrm{was}$ administered from the day before to the fifth day after cisplatin $(7 \mathrm{mg} / \mathrm{kg}$, i.p.) injection. Daily administration of bLf histologically reduced renal tubular injury induced by cisplatin and suppressed the deterioration of renal function. Accumulated platinum content in the kidney was significantly decreased by the daily administration of bLf. Moreover, the administration of intravenous bLf caused a significant increase in urine volume in a dose-dependent manner. These results suggest that pretreatment with bLf produces a protective effect against cisplatininduced nephrotoxicity. This protective effect of bLf involves the reduction of accumulated cisplatin in the kidney.

KEY WORDS: cisplatin, diuresis, lactoferrin, nephrotoxicity.

doi: 10.1292/jvms.12-0154; J. Vet. Med. Sci. 75(2): 159-164, 2013

Cisplatin (cis-diamminedichloroplatinum II) is one of the most effective chemotherapeutic agents used to treat a variety of solid tumors, but it has limited clinical application because it leads to the development of nephrotoxicity [30]. It is well known that cisplatin administered to rats damages the proximal tubule $[2,4,14,16,19,21]$ and that the kidney injury induced by cisplatin is similar to ischemic damage $[6$, 29]. The acute renal failure caused by cisplatin is typically characterized by signs such as a severe reduction in the glomerular filtration rate (GFR) [24], a variable fall in the renal blood flow $[6,29]$, a decrease in urinary concentrating ability and changes in urine volume and creatinine clearance [20]. It is essential to develop practical ways to counteract or minimize the side effects of cisplatin.

Lactoferrin (Lf), an iron-binding glycoprotein with a molecular weight of approximately $80 \mathrm{kDa}$, is found in milk, tears, saliva, and other external secretions, and in the secondary granules of neutrophils. Some physiological effects of Lf have been reported, including anti-inflammatory [15, 32], antinociception $[9,10]$, antistress $[13,26]$, anti-oxidant [28], cell proliferative [5] and immunoregulatory properties [1, 31]. Åbrink et al. [1], investigating the expression of Lf in the human kidney, showed that Lf may act as an anti-oxidant defense systems protecting the kidney against nonmicrobial oxidative injury. However, to our knowledge, there have been no published studies to date on the protec-

\footnotetext{
*Correspondence to: Takeuchi, T., Course of Veterinary Laboratory Medicine, School of Veterinary Medicine, Faculty of Agriculture, Tottori University, Tottori 680-8553, Japan.

e-mail: takeuchi@muses.tottori-u.ac.jp

(C)2013 The Japanese Society of Veterinary Science
}

tive effect of Lf against nephrotoxicity.

To clarify the physiological effects of Lf, the characteristic transporting system for $\mathrm{Lf}$ has been investigated. Takeuchi et al. [27] demonstrated that intraduodenally administered bovine $\mathrm{Lf}$ (bLf) is transported into the blood circulation via thoracic duct lymph fluid in adult rats. Their findings indicate that the bLf transported to epithelial cells from the lumen reaches the blood circulation via the lymphatic pathway, suggesting that it could be distributed to the whole body if an effective dose was administered.

In the present study, we assessed the protective effect of bLf on cisplatin-induced nephrotoxicity in rats. We also investigated whether bLf affects the accumulation of platinum $(\mathrm{Pt})$ in the kidney.

\section{MATERIALS AND METHODS}

Animals: Seven-week-old male Wistar rats were obtained from the Institute of Animal Reproduction (Ibaraki, Japan). The animals were maintained at a controlled temperature of $24 \pm 1^{\circ} \mathrm{C}$ with a $12-12 \mathrm{hr}$ light-dark cycle (light cycle, 07:00-19:00), and were given standard chow (CE-2; Nihon Clea, Tokyo, Japan). The use of these animals and the procedures performed were approved by the Animal Research Committee of Tottori University.

Chemicals: Cisplatin was purchased from Nippon Kayaku (Tokyo, Japan), and bLf was purchased from Wako Chemical Co., Ltd. (Osaka, Japan).

Blood chemistry and histological analysis of the kidney: Twenty-four rats were randomly divided into four groups of six rats each. The rats in the control group were orally administered saline $(3 \mathrm{ml} / \mathrm{kg})$ daily from the day before the study began (Day 0) to the fifth day (Day 5) of the study. Saline (14 
$\mathrm{ml} / \mathrm{kg}$, i.p.) was injected to the rat on Day 1 . The rats in the bLf alone group were orally administered bLf $(300 \mathrm{mg} / \mathrm{kg})$ daily from Day 0 to Day 5 , and injected with saline $(14 \mathrm{ml}$ $\mathrm{kg}$, i.p.) on Day 1. The rats in the cisplatin alone group were orally administered saline $(3 \mathrm{ml} / \mathrm{kg})$ daily from Days 0 to 5 , and injected with cisplatin ( $7 \mathrm{mg} / \mathrm{kg}$, i.p.) $2 \mathrm{hr}$ after the saline administration on Day 1. This dose of cisplatin has been well documented to induce nephrotoxicity in rats [2]. The rats in the cisplatin+bLf group were orally administered bLf (300 $\mathrm{mg} / \mathrm{kg}$ ) daily from Days 0 to 5 and injected with cisplatin (7 $\mathrm{mg} / \mathrm{kg}$, i.p.) $2 \mathrm{hr}$ after the bLf administration on Day 1. On Day 5 , the rats were anesthetized with sodium pentobarbital (Somnopentyl, 50 mg/kg, i.p.; Kyoritu Pharmaceutical Co., Ltd., Tokyo, Japan), and blood samples were collected from the caudal venae cavae. These samples were transferred to heparinized tubes, and then centrifuged at $4^{\circ} \mathrm{C}$ for $15 \mathrm{~min}$. Plasma was separated and stored at $-20^{\circ} \mathrm{C}$, until biochemical analyses were performed. Plasma BUN and creatinine were determined by means of a biochemical autoanalyzer (DriChem 3000 V3.1-P01; Fuji Film Co., Tokyo, Japan). Both kidneys were rapidly removed, and the blood was washed away with saline. Each kidney was sliced longitudinally, and one piece from each side of the kidney was fixed in $10 \%$ neutral buffered formalin. The kidney tissues were processed for histological examination by the conventional method [25], and stained with hematoxylin and eosin (HE).

Effect of bLf on the accumulation of cisplatin in the kidney: Forty rats were divided into four groups (control, bLf alone, cisplatin alone, and cisplatin+bLf) of 10 rats each. Oral administration (saline or bLf) and intraperitoneal injection (saline or cisplatin) were the same as described above. The collection of blood and kidneys was carried out on Day 2, because it is well known that the onset of oxidation damage in the kidney is at around $48 \mathrm{hr}$ after the cisplatin injection. After $48 \mathrm{hr}$ of saline or cisplatin treatment, the rats were anesthetized with sodium pentobarbital (Somnopentyl, $50 \mathrm{mg} / \mathrm{kg}$, i.p.), and blood samples were collected from the caudal venae cavae. A kidney was removed from each rat and weighed, and then stored at $-20^{\circ} \mathrm{C}$ until the analysis of the accumulated Pt content. The kidney tissue was decomposed to mimic pyrolysis by adding nitric acid and hydrogen peroxide. Pt was measured using an inductively coupled plasma-optical emission spectrometry (ICP-OES) system (Optima 4300DV; PerkinElmer Japan, Yokohama, Japan). The range of Pt measurement was 0-500 ppb. The accumulated Pt contents in the kidney were represented as $\mu \mathrm{g} / \mathrm{g}$ tissue.

Diuretic effect of bLf in normal rats: Seven healthy rats were used for this experiment. Under general anesthesia with $25 \%$ urethane $(1 \mathrm{~g} / \mathrm{kg}$, s.c.) and sodium pentobarbital (Somnopentyl, $25 \mathrm{mg} / \mathrm{kg}$, i.p.), a cannula was inserted into the external jugular vein to control the depth of anesthesia by an additional injection of sodium pentobarbital. Saline $(4.5 \mathrm{ml} /$ $\mathrm{kg} / \mathrm{hr}$ ) was infused constantly by syringe pump (TOP-5300, TOP Co., Ltd., Tokyo, Japan) to maintain blood circulation and blood pressure. Another cannula was inserted into the external carotid artery to monitor blood pressure via an amplifier (PowerLab; ADInstruments, Sydney, Australia). The heart rates of all rats were also monitored by electrocardiography (PowerLab; ADInstruments). Body temperature was monitored by a rectangular sensor (SK-1250MC III $\alpha$; Sato Keiryoki Mfg. Co., Ltd., Tokyo, Japan). During the experiment, the blood pressure of the rats was maintained within the range of $80-120 \mathrm{mmHg}$, the heart rate within $270-330$ $\mathrm{BPM}$, and the body temperature within $36.5-37.0^{\circ} \mathrm{C}$. An abdominal midline incision was made in each rat, and the bladder and both ureters were exposed. Polyethylene tubes (SP-10; Natsume Co., Ltd., Tokyo, Japan) were placed into both ureters. BLf was administered to the rats through the external jugular vein at three doses $(3,10$ and $30 \mathrm{mg} / \mathrm{kg})$ at 40,100 and $160 \mathrm{~min}$ after the start of urine sampling. During the procedures, urine samples were collected into plastic tubes every $10 \mathrm{~min}$, and urine volume was measured.

Statistical analysis: All data are expressed as means $\pm \mathrm{SE}$. Statistical comparisons were performed by analysis of variance (ANOVA) followed by Tukey's multiple comparison tests. A probability level of $P<0.05$ was considered statistically significant.

\section{RESULTS}

Effect of bLf on blood chemistry and histological findings in the kidney: Figure 1 shows the effects of bLf on the plasma concentrations of BUN (Fig. 1A) and creatinine (Fig. 1B) in normal rats and rats with acute renal failure induced by cisplatin administration. The administration of bLf alone did not change BUN or creatinine. Cisplatin caused a significant increase in BUN $(14.47 \pm 0.38 \mathrm{mg} / \mathrm{d} l$ in the control group and $124.32 \pm 11.39 \mathrm{mg} / \mathrm{d} l$ in the cisplatin alone group) and creatinine $(0.17 \pm 0.02$ and $2.56 \pm 0.17 \mathrm{mg} / \mathrm{d} l$, respectively). These renal abnormalities induced by cisplatin were significantly improved by pretreatment with oral bLf (the cisplatin+bLf group).

Histopathological examination of the kidney revealed that cisplatin strongly impaired proximal tubule. In the cisplatin alone group (Fig. 2C and 2E), marked tubular necrosis was observed especially in the straight portion of the proximal tubule in the outer stripe of the medulla, while bLf alone and saline groups (Fig. 2A and 2B, respectively) did not cause any pathological changes. The lesions in the cisplatin $+\mathrm{bLf}$ group were smaller and milder than those of cisplatin alone group (Fig. 2D and 2F). BLf administration was found to reduce the epithelial damage induced by cisplatin.

Effect of bLf on the accumulation of cisplatin in the kidney: The accumulated Pt contents in the kidney were measured at $48 \mathrm{hr}$ after saline or cisplatin $(7 \mathrm{mg} / \mathrm{kg}$, i.p.) treatment (Table 1). As reported in the previous study [14], the tubular damages occurred at $48 \mathrm{hr}$ after cisplatin treatment. The $\mathrm{Pt}$ contents in the cisplatin alone and the cisplatin $+\mathrm{bLf}$ groups were $16.70 \pm 1.96$ and $9.8 \pm 2.1 \mu \mathrm{g} / \mathrm{g}$ tissue, respectively (Table 1). The Pt content in the kidney was decreased significantly by bLf treatment. In this experiment, the BUN and creatinine concentrations in plasma were also measured at $48 \mathrm{hr}$ after saline or cisplatin $(7 \mathrm{mg} / \mathrm{kg}$, i.p.) injection. The administration of bLf (300 mg/kg, p.o.) alone did not affect BUN or creatinine, while cisplatin caused a mild increase 

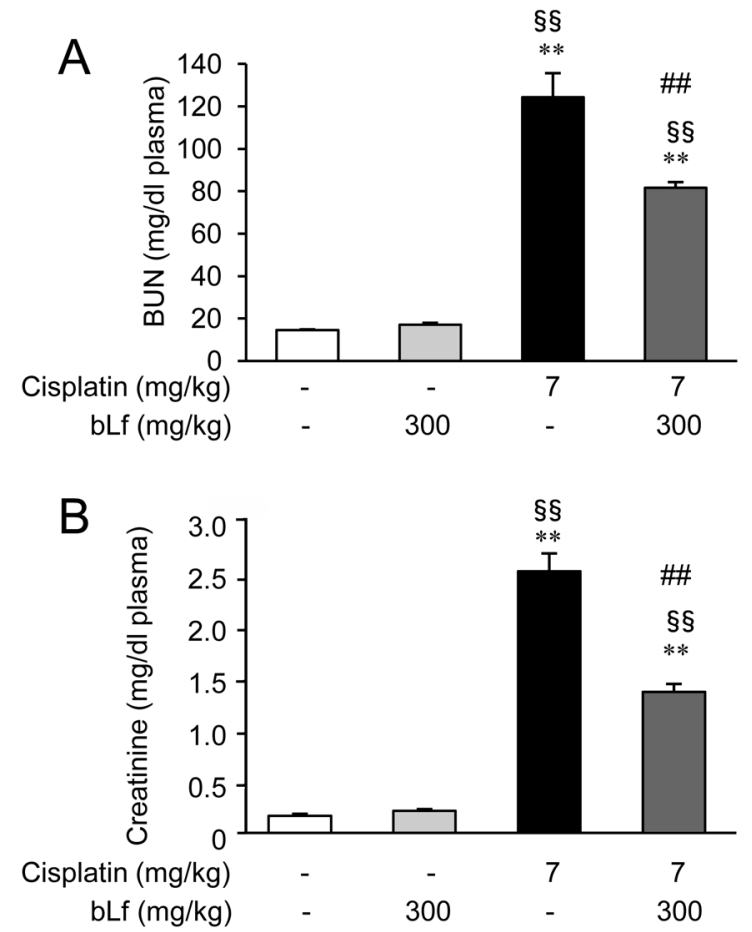

Fig. 1. Effect of bLf administration on the plasma concentrations of BUN and creatinine in cisplatin-induced renal injury. Each graph shows the plasma concentrations of BUN (A) and creatinine (B) in the cisplatin-induced rats on the 5th day after the cisplatin $(7 \mathrm{mg} / \mathrm{kg})$ injection. BLf $(300 \mathrm{mg} / \mathrm{kg})$ was orally administered in the bLf alone and cisplatin $+\mathrm{bLf}$ groups from Day 0 to Day 5. Data represent means \pm SE from 6 rats. Significant differences are shown as **; $P<0.01$ vs. control group, $\S \S ; P<0.01$ vs. bLf alone group, and \#\#; $P<0.01$ vs. cisplatin alone group, respectively.

in both (cisplatin alone group). These changes induced by cisplatin were significantly improved by pretreatment with oral bLf (cisplatin+bLf group).

Diuretic effect of bLf in normal rats: Intravenous bLf administration caused a significant increase in urine volume in a dose-dependent manner (Fig. 3A). Compared with the average urine volume during the first $30 \mathrm{~min}$, those values after 10 and $30 \mathrm{mg} / \mathrm{kg}$ bLf administrations resulted in increments of 157 and $250 \%$, respectively. There were no significant effects of bLf on an arterial blood pressure and a heart rate (Fig. 3B and 3C).

\section{DISCUSSION}

The present study indicated that orally administered bLf has a protective effect against the acute renal failure induced by cisplatin in rats. This protective effect of bLf was suggested by biochemical and morphological evidences, including lower BUN and creatinine levels and lower damage in the proximal tubles compared with the cisplatin alone group.

We also demonstrated that the Pt content in the kidneys in the cisplatin+bLf group was significantly lower than that in the cisplatin alone group. Esteban-Fernandez et al. [7] reported that the maximum concentration of $\mathrm{Pt}$ in the kidney was achieved within the third day after the cisplatin treatment in rats. In our previous study, proximal tubular injury developed from the second day to the fourth day after the cisplatin injection [14]. Therefore, we measured the Pt content in the kidney at $48 \mathrm{hr}$ after the cisplatin injection. Muenyi et al. [17] reported that the systemic Pt accumulation occurred in the following order: kidney $>$ liver $=$ spleen $>$ heart $>$ brain. It is well known the accumulated Pt contributes to the occurrence of damage to the proximal tubules. However, Esteban-Fernandez et al. [7] mentioned that the toxic effects produced by cisplatin in the kidney are probably not only related to the Pt accumulation and distribution, but also to the drug-biomolecule interaction, because they found that two fractions ranging below $50 \mathrm{kDa}$ represented approximately $50 \%$ of the total Pt in the cytosol of the kidney. In any case, the reduction of accumulated Pt in the kidney might be related with the prevention of tubular damage induced by cisplatin.

In the present study, intravenous injection of bLf caused diuresis in a dose-dependent manner. Cisplatin causes decreased renal blood flow by renal vasoconstriction as well as ischemic damage in the proximal tubule [6, 20, 24, 29]. It is well known that several diuretic drugs such as furosemide and mannitol have a renoprotective effect in cisplatin-treated animals [18]. The increment of urine volume leads to suppression of the reabsorption of cisplatin at the proximal tubules. In our study, urine volume increased up to 2.5 times higher than the basal volume when the rat received bLf at a dose of $30 \mathrm{mg} / \mathrm{kg}$. Hayashida et al. [11] reported that bLf causes a nitric oxide (NO)-dependent relaxation of smooth muscle in the rat's aorta, suggesting that bLf can affect the blood circulation in individual organs. The involvement of NO in the renoprotective effect in cisplatin-injected rats was supported by a treatment with L-arginine resulting in NO modulation [22]. Hydration with saline also has a renoprotective effect on cisplatin-injected rats [23]. In our experiment regarding the diuretic effect of bLf, the rats were infused with saline throughout the experimental period to maintain the blood circulation. Saline infusion had no significant effects on the urine volume, heart rate or blood pressure by itself. In contrast, bLf resulted in a significant increase in the urine volume without affecting the heart rate or blood pressure. Further experiments are required to clarify the precise mechanisms of the diuretic effect of bLf.

For the clinical application of bLf, the oral route may be safest, because bLf has a risk of antigenicity. Atkinson and Meredith [3] reported that bLf given through i.p. exhibited antigenicity in the Brown Norway rat model using carrageenan as an adjuvant. Ishikado et al. [12] also compared the oral administration and subcutaneous administration of bLf in guinea pigs in terms of antigenicity. Their report indicated that the oral administration caused less passive cutaneous anaphylaxis than the subcutaneous administration. In the present study, orally administered bLf actually indicated the protective effect on the cisplatin-induced renal failure. 

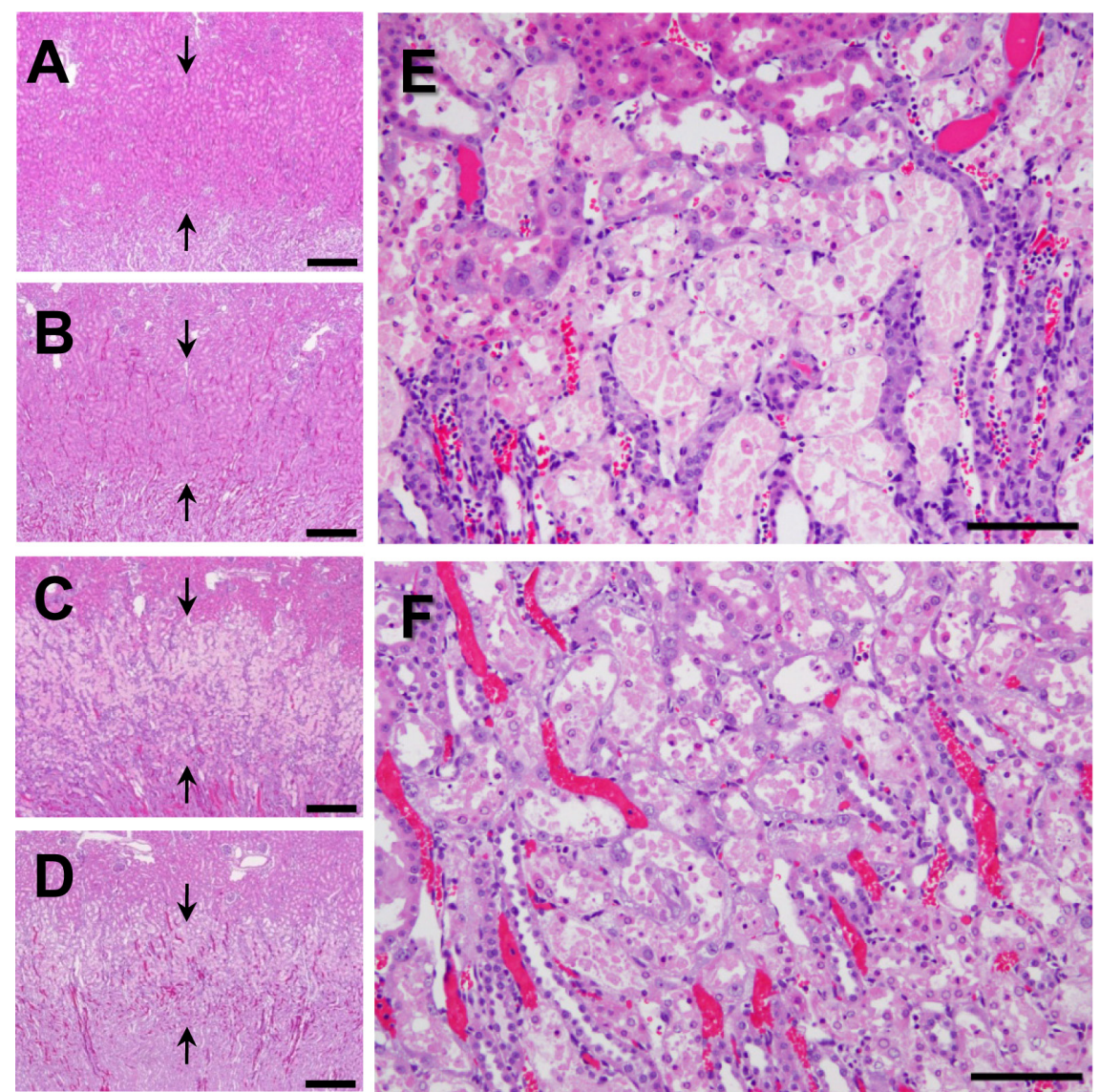

Fig. 2. Histopathological findings of cisplatin-induced renal tubular injury. Bar=500 $\mu \mathrm{m}(\mathrm{A}-\mathrm{D})$. $\mathrm{Bar}=50 \mu \mathrm{m}$ (E and F). Photographs A-D show low magnification. Photographs E and F show high magnification. A: saline, B: bLf alone, $\mathrm{C}$ and $\mathrm{E}$ : cisplatin alone, D and F: cisplatin+bLf. Cisplatin treatment caused severe renal tubular injury in the outer stripe of the medulla (arrows) in the cisplatin alone group (C). The injured area was smaller and milder in the cisplatin $+\mathrm{bLf}$ group $(\mathrm{D}$ and $\mathrm{F})$ than the cisplatin alone group $(\mathrm{C}$ and $\mathrm{E})$.

Table 1. Effect of bLf administration on the plasma concentrations of BUN and creatinine and the Pt content in the kidney tissue in cisplatin-induced renal injury

\begin{tabular}{lccc}
\hline Group & BUN $(\mathrm{mg} / \mathrm{d} l)$ & Creatinine $(\mathrm{mg} / \mathrm{d} l)$ & Pt content $(\mu \mathrm{g} / \mathrm{g}$ tissue $)$ \\
\hline Saline & $14.87 \pm 0.49$ & $0.13 \pm 0.02$ & N.D. \\
BLf alone & $16.24 \pm 0.69$ & $0.11 \pm 0.01$ & N.D. \\
Cisplatin alone & $24.32 \pm 1.86^{* *}$ & $0.31 \pm 0.03^{* *}$ & $16.7 \pm 1.96$ \\
Cisplatin+bLf & $18.26 \pm 1.66$ & $0.15 \pm 0.02^{\# \#}$ & $9.8 \pm 2.1^{\#}$ \\
\hline
\end{tabular}

All rats were evaluated at $48 \mathrm{hr}$ after the administration of saline or cisplatin $(7 \mathrm{mg} / \mathrm{kg}$, ip). Data represent means $\pm \mathrm{SE}$ from 10 rats. Significant differences are shown as **; $P<0.01$ vs. saline group, \#\#; $P<0.01$ vs. cisplatin alone group, and \#; $P<0.05$ vs. cisplatin alone group. N.D.: not detected.

In our previous study, orally administered Lf was detected in plasma as an intact protein [8]. Moreover, we demonstrated that intraduodenally administered bLf is transported into the blood circulation via thoracic duct lymph fluid in adult rats [27]. These characteristic transportation systems of Lf contribute to its variety of clinical effects throughout the body.
In conclusion, the present study indicates that pretreatment with bLf produces a protective effect against cisplatininduced nephrotoxicity. It is also suggested that bLf evokes diuresis and reduces the accumulation of cisplatin in the kidney. 


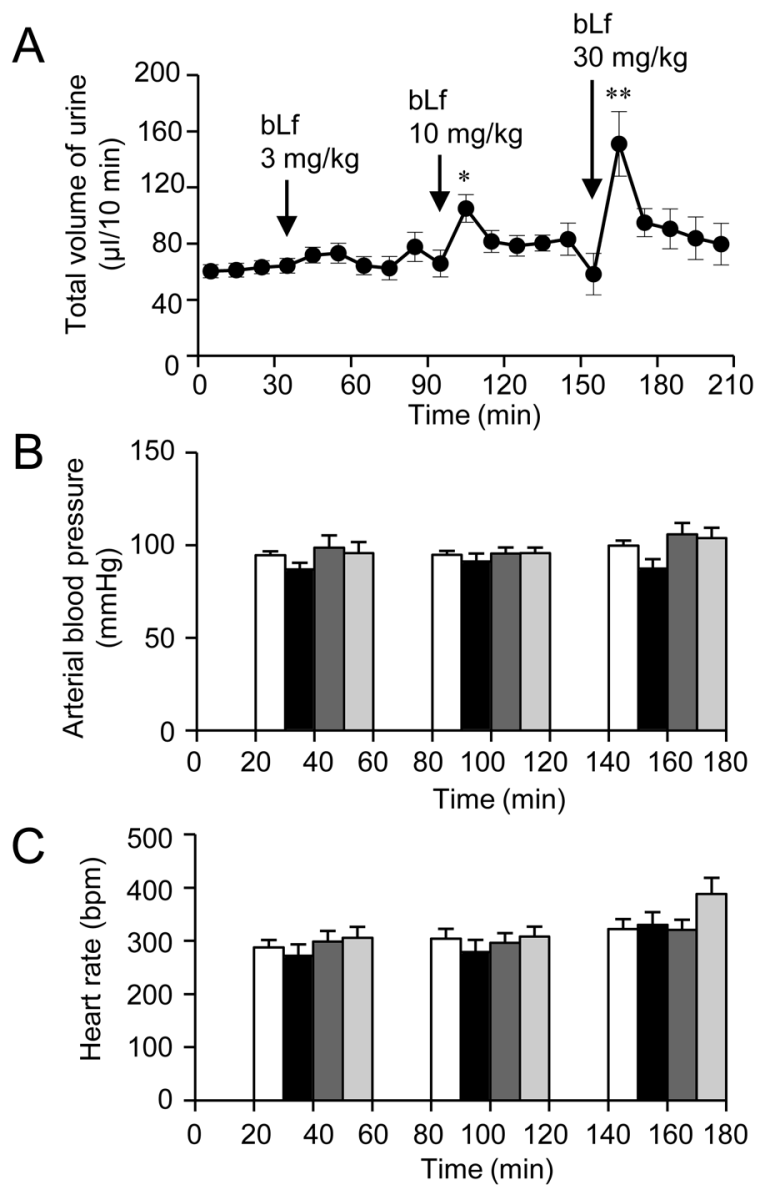

Fig. 3. Time course of urine output and the diuretic effect of bLf in normal rats. Each graph shows the total value of the urine (A), arterial blood pressure (B) and heart rate (C), respectively. Three doses of bLf $(3,10$ and $30 \mathrm{mg} / \mathrm{kg}$ ) were intravenously administered at 40, 100 and $160 \mathrm{~min}$ after the start of urine sampling. With respect to the arterial blood pressure (B) and heart rate $(\mathrm{C})$, the effect of the drug was compared with the value measured $10 \mathrm{~min}$ before each drug injection. Each column shows the mean value in each 10-min interval. Data represent means $\pm \mathrm{SE}$ from 7 rats. Significant differences are shown as *, **, corresponding to $P<0.05, P<0.01$ vs. the average volume of urine during the first $30 \mathrm{~min}$, respectively.

\section{REFERENCES}

1. Åbrink, M., Larsson, E., Gobl, A. and Hellman, L. 2000. Expression of lactoferrin in the kidney: implications for innate immunity and iron metabolism. Kidney Int. 57: 2004-2010. [Medline] [CrossRef]

2. Atessahin, A., Yilmaz, S., Karahan, I., Ceribasi, A. O. and Karaoglu, A. 2005. Effects of lycopene against cisplatin-induced nephrotoxicity and oxidative stress in rats. Toxicology 212: 116-123. [Medline] [CrossRef]

3. Atkinson, H. A. C. and Meredith, C. 1998. Assessment of allergenic potential of novel proteins in food crops using the brown Norway rat model. pp. 70-75. In: Proceedings of the 3rd Karlsruhe Nutrition Symposium.
4. Chang, B., Nishikawa, M., Sato, E., Utsumi, K. and Inoue, M. 2002. L-Carnitine inhibits cisplatin-induced injury of the kidney and small intestine. Arch. Biochem. Biophys. 405: 55-64. [Medline] [CrossRef]

5. Cornish, J., Callon, K. E., Naot, D., Palmano, K. P., Banovic, T., Bava, U., Watson, M., Lin, J. M., Tong, P. C., Chen, Q., Chan, V. A., Reid, H. E., Fazzalari, N., Baker, H. M., Baker, E. N., Haggarty, N. W., Grey, A. B. and Reid, I. R. 2004. Lactoferrin is a potent regulator of bone cell activity and increases bone formation in vivo. Endocrinology 145: 4366-4374. [Medline] [CrossRef]

6. Dobyan, D. C., Levi, J., Jacobs, C., Kosek, J. and Weiner, M. W. 1980. Mechanism of cis-platinum nephrotoxicity: II. Morphologic observations. J. Pharmacol. Exp. Ther. 213: 551-556. [Medline]

7. Esteban-Fernandez, D., Verdaguer, J. M., Ramirez-Camacho, R., Palacios, M. A. and Gomez-Gomez, M. M. 2008. Accumulation, fractionation, and analysis of platinum in toxicologically affected tissues after cisplatin, oxaliplatin, and carboplatin administration. J. Anal. Toxicol. 32: 140-146. [Medline]

8. Harada, E., Itoh, Y., Sitizyo, K., Takeuchi, T., Araki, Y. and Kitagawa, H. 1999. Characteristic transport of lactoferrin from the intestinal lumen into the bile via the blood in piglets. Comp. Biochem. Physiol. A Mol. Integr. Physiol. 124: 321-327. [Medline] [CrossRef]

9. Hayashida, K., Takeuchi, T., Shimizu, H., Ando, K. and Harada, E. 2003. Novel function of bovine milk-derived lactoferrin on antinociception mediated by $\mu$-opioid receptor in the rat spinal cord. Brain Res. 965: 239-245. [Medline] [CrossRef]

10. Hayashida, K., Takeuchi, T., Shimizu, H., Ando, K. and Harada, E. 2003. Lactoferrin enhances opioid-mediated analgesia via nitric oxide in the rat spinal cord. Am. J. Physiol. Regul. Integr. Comp. Physiol. 285: R306-R312. [Medline]

11. Hayashida, K., Takeuchi, T., Ozaki, T., Shimizu, H., Ando, K., Miyamoto, A. and Harada, E. 2004. Bovine lactoferrin has a nitric oxide-dependent hypotensive effect in rats. Am. J. Physiol. Regul. Integr. Comp. Physiol. 286: R359-R365. [Medline] [CrossRef]

12. Ishikado, A., Imanaka, H., Takeuchi, T., Harada, E. and Makino, T. 2005. Liposomalization of lactoferrin enhanced it's antiinflammatory effects via oral administration. Biol. Pharm. Bull. 28: 1717-1721. [Medline] [CrossRef]

13. Kamemori, N., Takeuchi, T., Hayashida, K. and Harada, E. 2004. Suppressive effects of milk-derived lactoferrin on psychological stress in adult rats. Brain Res. 1029: 34-40. [Medline] [CrossRef]

14. Kimoto, Y., Sugiyama, A., Nishinohara, M., Asano, A., Matsuda, A., Ochi, T. and Takeuchi, T. 2011. Expressions of protein oxidation markers, dityrosine and advanced oxidation protein products in cisplatin-induced nephrotoxicity in rats. J. Vet. Med. Sci. 73: 403-407. [Medline] [CrossRef]

15. Koike, D. and Makino, I. 1993. Protective effect of lactoferrin on caerulein-induced acute pancreatitis in rats. Digestion 54: 84-90. [Medline] [CrossRef]

16. Martinez, G., Costantino, G., Clementi, A., Puglia, M., Clementi, S., Cantarella, G., Meo, L. D. and Matera, M. 2009. Cisplatin-induced kidney injury in the rat: L-carnitine modulates the relationship between MMP-9 and TIMP-3. Exp. Toxicol. Pathol. 61: 183-188. [Medline] [CrossRef]

17. Muenyi, C. S., States, V. A., Masters, J. H., Fan, T. W., Helm, C. W. and States, J. C. 2011. Sodium arsenite and hyperthermia modulate cisplatin-DNA damage responses and enhance platinum accumulation in murine meteatatic ovarian cancer xeno- 
graft after hyperthermic intraperitoneal chemotherapy (HIPEC). J. Ovarian Res. 4: 9-19. [Medline] [CrossRef]

18. Nagai, N. and Ogata, H. 1996. The renal clearance of unchanged cisplatin during furosemide and mannitol diuresis is dependent on glomerular filtration rate in rats. J. Pharm. Sci. 85: 720-724. [Medline] [CrossRef]

19. Naghizadeh, B., Boroushaki, M. T., Mashhasian, N. V. and Mansouri, S. M. T. 2008. Protective effects of crocin against cisplatin-induced acute renal failure and oxidative stress in rats. Iran. Biomed. J. 12: 93-100. [Medline]

20. Nishikawa, M., Nagatomi, H., Chang, B. J., Sato, E. and Inoue, M. 2001. Targeting superoxide dismutase to renal proximal tubule cells inhibits mitochondrial injury and renal dysfunction induced by cisplatin. Arch. Biochem. Biophys. 387: 78-84. [Medline] [CrossRef]

21. Pabla, N. and Dong, Z. 2008. Cisplatin nephrotoxicity: mechanisms and renoprotective strategies. Kidney Int. 73: 994-1007. [Medline] [CrossRef]

22. Saleh, S. and El-Demerdash, E. 2005. Protective effects of L-arginine against cisplatin-induced renal oxidative stress and toxicity: role of nitric oxide. Basic Clin. Pharmacol. Toxicol. 97: 91-97. [Medline] [CrossRef]

23. Santoso, J. T., Lucci, J. A. III., Coleman, R. L., Schafer, I. and Hannigan, E. V. 2003. Saline, mannitol, and furosemide hydration in acute cisplatin nephrotoxicity: a randomized trial. Cancer Chemother. Pharmacol. 52: 13-18. [Medline] [CrossRef]

24. Stein, J. H. and Fried, T. A. 1985. Experimental models of nephrotoxic acute renal failure. Transplant. Proc. 17: 72-80. [Medline]

25. Sugiyama, A., Sato, A. and Takeuchi, T. 2009. PEGylated lactoferrin enhanced its hepatoprotective effects on acute liver injury induced by carbon tetrachloride in rats. Food Chem. Toxicol. 47: 1453-1458. [Medline] [CrossRef]
26. Takeuchi, T., Hayashida, K., Inagaki, H., Kuwahara, M., Tsubone, H. and Harada, E. 2003. Opioid mediated suppressive effect of milk-derived lactoferrin on distress induced by maternal separation in rat pups. Brain Res. 979: 216-224. [Medline] [CrossRef]

27. Takeuchi, T., Kitagawa, H. and Harada, E. 2004. Evidence of lactoferrin transportation into blood circulation from intestine via lymphatic pathway in adult rats. Exp. Physiol. 89: 263-270. [Medline] [CrossRef]

28. Tsubota, A., Yoshikawa, T., Narai, K., Mitsunaga, M., Yumoto, Y., Fukushima, K., Hoshina, S. and Fujise, K. 2008. Bovine loctoferrin potently inhibits liver mitochondrial 8-OHdG levels and retrieves hepatic OGG1 activities in Long-Evans Chinnamon rats. J. Hepatol. 48: 486-493. [Medline] [CrossRef]

29. Venkatachalam, M. A., Bernard, D. B., Donohoe, J. F. and Levinsky, N. G. 1978. Ischemic damage and repair in the rat proximal tubule: differences among the $\mathrm{S}_{1}, \mathrm{~S}_{2}$, and $\mathrm{S}_{3}$ segments. Kidney Int. 14: 31-49. [Medline] [CrossRef]

30. Weijl, N. I., Elsendoorn, T. J., Lentjes, E. G., Hopman, G. D., Wipkink-Bakker, A., Zwinderman, A. H., Cleton, F. J. and Osanto, S. 2004. Supplementation with antioxidant micronutrients and chemotherapy-induced toxicity in cancer patients treated with cisplatin-based chemotherapy: a randomized, double-blind, placebo-controlled study. Eur. J. Cancer 40: 1713-1723. [Medline] [CrossRef]

31. Zimecki, M., Artym, J., Chodaczek, G., Kocieba, M., Kuryszko, J., Houszka, M. and Kruzel, M. 2007. Immunoregulatory function of lactoferrin in immunosuppressed and autoimmune animals. Postepy Hig. Med. Dosw. (Online) 61: 283-287. [Medline]

32. Zimecki, M., Kocieba, M., Chodaczek, G., Houszka, M. and Kruzel, M. L. 2007. Lactoferrin ameliorates symptoms of experimetntal encephalomyelitis in Lewis rats. J. Neuroimmunol. 182: 160-166. [Medline] [CrossRef] 